\title{
Interaction between Mammalian Glyceraldehyde-3- phosphate Dehydrogenase and L-Lactate Dehydrogenase from Heart and Muscle
}

\author{
Željko M. Svedružić* and H. Olin Spivey \\ Department of Biochemistry and Molecular Biology, 246 B Noble Research Center, Oklahoma State University, \\ Stillwater, Oklahoma 74078
}

\begin{abstract}
The exceptionally high protein concentration in living cells can favor functional protein-protein interactions that can be difficult to detect with purified proteins. In this study we describe specific interactions between mammalian D-glyceraldehyde-3-phosphate dehydrogenase (GAPDH) and Llactate dehydrogenase (LDH) isozymes from heart and muscle. We use poly(ethylene-glycol) (PEG)induced coprecipitation and native agarose electrophoresis as two independent methods uniquely suited to mimic some of the conditions that can favor protein-protein interaction in living cells. We found that GAPDH interacts with heart or muscle isozymes of $\mathrm{LDH}$ with approximately one-to-one stoichiometry. The interaction is specific; GAPDH shows interaction with two LDH isozymes that have very different net charge and solubility in PEG solution, while no interaction is observed with GAPDH from other species, other NAD(H) dehydrogenases, or other proteins that have very similar net charge and molecular mass. Analytical ultracentrifugation showed that the LDH and GAPDH complex is insoluble in PEG solution. The interaction is abolished by saturation with NADH, but not by saturation with $\mathrm{NAD}^{+}$in correlation with GAPDH solubility in PEG solution. The crystal structures show that GAPDH and LDH isozymes share complementary size, shape, and electric potential surrounding the active sites. The presented results suggest that GAPDH and LDH have a functional interaction that can affect $\mathrm{NAD}^{+} / \mathrm{NADH}$ metabolism and glycolysis in living cells. Proteins 2006;63:501-511.

๑) 2006 Wiley-Liss, Inc.
\end{abstract}

Key words: molecular crowding; excluded volume effect; supramolecular organization; metabolic regulation; metabolon

\section{INTRODUCTION}

The total protein concentration in cytosol is in the range from 200 to $400 \mathrm{mg} / \mathrm{mL},{ }^{1-4}$ while the protein concentration in mitochondrial matrix can be as high as $560 \mathrm{mg} / \mathrm{mL} .^{1,5,6}$ At such high concentrations macromolecules occupy a large fraction of solution volume (i.e., $20-50 \%{ }^{1}$ ), which results in molecular crowding and the excluded volume effect. $^{4,7-9}$ The excluded volume effect leads to lower solubility of macromolecules, transitions to more compact macromolecular conformations, ${ }^{10}$ and tens of $\mathrm{kJ} / \mathrm{mol}$ of free energy in support of protein-protein interaction, ${ }^{4,7-9}$ Cell physiology depends on protein-protein interactions, ${ }^{11}$ and in some cases protein complexes can be isolated and functionally described. However, some functional protein interactions are only transient ${ }^{12}$ or exist only in the presence of molecular crowding effects in living cells. ${ }^{11,13}$ Such interactions are broken during protein purification, ${ }^{13}$ and their existence and functional properties are unknown, or even controversial. ${ }^{14}$ In essence, the connection between protein function in vitro and in the concentrated protein solutions present in vivo is a fundamental question in biochemistry. ${ }^{11}$

Functional protein-protein interactions present in living cells are perhaps best understood for enzymes in the mitochondrial matrix. ${ }^{15,16}$ Those studies showed that often only innovative in vivo and in vitro experiments could address the delicate nature of protein-protein interactions in living cells. ${ }^{15,16}$ For example, in situ NMR studies with asymmetrically labeled metabolites showed that in yeast cells the enzymes in the TCA cycle can share common metabolites by substrate channeling. ${ }^{17,18}$ Catalytically inactive $\mathrm{NAD}^{+}$-isocitrate dehydrogenase that is still capable of forming functional interactions with related enzymes could restore metabolic function in yeast cells. ${ }^{19}$ The same process could not be restored by catalytically active isozyme that participates in another metabolic pathway. Interestingly, despite strong evidence that the enzymes in the TCA cycle have functional interactions in living cells, studies with purified proteins did not show protein-protein interactions except under very specific conditions. ${ }^{20-25}$ For example, the interaction between citrate synthase and malate dehydrogenase can

H.O. Spivey is retired.

This article was approved for publication by the Director, Oklahoma Agricultural Experimental Station (OAES).

Grant sponsor: NSF; Grant numbers: MCB-9513613, MCB-0080258; Grant sponsor: Oklahoma Center for Advancement of Science and Technology (OCAST); Grant number: HR-061; Grant sponsor: OAES Project; Grant number: OKLO-1393.

*Correspondence to: Željko M. Svedružić, School of Molecular Biosciences, Department of Biophysics and Biochemistry, Washington State University, Pullman, WA 99164. E-mail: zeljko@wsu.edu

Received 2 May 2005; Revised 15 August 2005; Accepted 22 September 2005

Published online 27 January 2006 in Wiley InterScience (www.interscience.wiley.com). DOI: 10.1002/prot.20862 
be detected only by PEG coprecipitation ${ }^{20,21}$ and native agarose electrophoresis. ${ }^{26}$ Nevertheless, the insoluble PEG-induced complex was active in substrate channeling, ${ }^{27}$ and substrate channeling could be observed when the two proteins were artificially connected by a linker peptide. $^{28}$

In cytosol, functional protein aggregates are organized around the cytoskeleton and membranes. ${ }^{29}$ Such aggregates form around proteins that bind cytoskeletal structures, such as glycolytic enzyme D-glyceraldehyde3-phosphate dehydrogenase (GAPDH), which binds to actin fibers $^{29,30}$ and microtubule networks. ${ }^{29,31}$ In fact, GAPDH shows some surprising effects on cell physiology that go well beyond its catalytic function as a glycolytic enzyme (reviewed by Sirover ${ }^{32}$ ). GAPDH is functionally associated with microtubule bundling, DNA replication and repair, apoptosis, export of nuclear RNA, membrane fusion, and phosphotransferase activity. GAPDH has also been implicated in neurodegenerative diseases such as Huntington's disease, as well as prostate cancer and viral pathogenesis. GAPDH could be a target of nitric oxide and a target of drugs developed to treat malaria or Alzheimer's disease.

GAPDH is the most abundant glycolytic enzyme, and the most abundant $\mathrm{NAD}(\mathrm{H})$ dehydrogenase that can bind the majority of cytosolic $\mathrm{NAD}(\mathrm{H}){ }^{33}$ An open question is to what extent is $\mathrm{NAD}(\mathrm{H})$ metabolism controlled by interaction between GAPDH and other cytosolic dehydrogenases. The first reports of possible interaction between $\mathrm{NAD}(\mathrm{H})$ dehydrogenases were published 50 years ago. ${ }^{34,35}$ Several studies indicated that GAPDH and LDH isozymes can be colocalized on cellular structures. ${ }^{29,36,37}$ Interaction between $\mathrm{NAD}(\mathrm{H})$ dehydrogenases in mitochondrial matrix has been reported on several occasions. ${ }^{23,38-40}$ Some studies have indicated that there could be $\operatorname{NAD}(\mathrm{H})$ channeling ${ }^{38,40,41}$ between cytosolic or mitochondrial $\mathrm{NAD}(\mathrm{H})$ dehydrogenases of opposite chiral specificity. ${ }^{42}$ However, some of the channeling results have been extensively debated. ${ }^{43-48}$ One of the criticisms of NADH channeling is the absence of a detectable complex between $\mathrm{NAD}(\mathrm{H})$ dehydrogenases. ${ }^{46-48}$

In this study we describe a specific interaction between purified rabbit muscle GAPDH and porcine muscle and heart isozymes of L-lactate dehydrogenase (LDH). We use PEG coprecipitation and native electrophoresis experiments as two independent techniques uniquely suited to demonstrate delicate protein-protein interaction that may be present in living cells. Using analytical ultracentrifugation we show that the PEG-induced complex between LDH and GAPDH is insoluble. Molecular modeling showed that GAPDH and the two LDH isozymes share complementary size, shape, and electrostatic surface potentials. In summary, these results support the earlier proposals that there could be some degree of separation between glycolysis and cellular $\mathrm{NAD}^{+} / \mathrm{NADH}$ pool $^{33,37,49}$ and give us a unique opportunity to analyze this phenomena using purified proteins.

\section{MATERIALS AND METHODS}

\section{Materials}

Ultrapure, high-strength agarose was purchased from Bio-Rad Laboratories (Hercules, CA). PEG 6000 and other chemicals were purchased from Sigma Chemical Co. (St. Louis, MO), unless otherwise indicated. $\mathrm{NAD}^{+}$and $\mathrm{NADH}$ were of $99 \%$ or better purity as listed. $\mathrm{D}(-) 3$-phosphoglyceric acid (98\% pure as listed) was obtained as the tri(cyclohexylammonium) salt. ATP was the grade I disodium salt. BSA was RIA grade, fraction V powder. Activated charcoal was hydrochloric acid washed, and cell culture tested. Ammonium sulfate suspensions of phLDH, pmLDH, porcine heart cytosolic malate dehydrogenase, rmGAPDH, porcine muscle GAPDH (pmGAPDH), rabbit muscle aldolase (rmALD), rabbit muscle glycerol-3-phosphate dehydrogenase, baker's yeast 3-phosphoglyceric phosphokinase, and Leuconostoc mesenteroides glucose-6-phosphate dehydrogenase were purchased from Sigma Chemical Co. or MP Biomedicals (Costa Mesa, CA). The Bacillus stearothermophlusGAPDH and baker's yeast GAPDH enzymes were obtained as lyophilized powders. All of the enzymes tested (all the enzymes listed above except the 3-phosphoglyceric phosphokinase and glucose-6-phosphate dehydrogenase enzymes) gave a single band in Coomassie Blue-stained, SDS-PAGE experiments. All absorbance measurements and enzyme assays were made on a Shimadzu UV-160U spectrophotometer at $25^{\circ} \mathrm{C}$. The buffer $\mathrm{pH}$ was adjusted at room temperature. $\mathrm{NADH}$ stock solutions were prepared in $120 \mathrm{mM} \mathrm{Na}_{2} \mathrm{CO}_{3}$ in a light-isolated container and used within 2 weeks of preparation. $\mathrm{NAD}^{+}$was freshly prepared before each experiment. ATP was prepared as a 100 $\mathrm{mM}$ stock solution in $10 \mathrm{mM}$ EDTA, $50 \mathrm{mM}$ Tris/ $\mathrm{HCl}$, stored at $-20^{\circ} \mathrm{C}$, and used within 3 months of preparation. The 3-phosphoglycerate was prepared as a $300 \mathrm{mM}$ solution in $300 \mathrm{mM}$ Tris base and stored at $-20^{\circ} \mathrm{C}$.

\section{Apo-Enzyme Preparations}

Prior to each experiment, enzyme suspensions were centrifuged to remove $\left(\mathrm{NH}_{4}\right)_{2} \mathrm{SO}_{4}$, and the pelleted enzyme dissolved in a specific buffer and dialyzed twice for at least $3 \mathrm{~h}$, each time against a 2000 -fold excess of buffer. After dialysis, the enzymes were treated with $1 \mathrm{mg}$ of charcoal per mg of protein to remove the tightly bound $\operatorname{NAD}(\mathrm{H}){ }^{50}$ The procedure was repeated twice for rmGAPDH and once for phLDH and pmLDH. This treatment routinely produced the highest absorbance ratios achieved by our laboratory $\left(1.8<\mathrm{A}_{260} / \mathrm{A}_{280}<2.0\right.$, depending on the protein). The efficiency of the charcoal treatment was tested enzymatically by recording absorbance changes at $340 \mathrm{~nm}$ for $30 \mathrm{~min}$. Residual NADH was determined by incubating enzyme (100-200 $\mu \mathrm{M}$ catalytic sites) with its substrate. Bound $\mathrm{NAD}^{+}$was measured by first heatdenaturing the enzyme, then assaying the $\mathrm{NAD}^{+}$using 2 $\mathrm{mM}$ glucose-6-phosphate and $L$. mesenteroides glucose-6phosphate dehydrogenase. Glucose-6-phosphate dehydrogenase is unique for its high preference for $\mathrm{NAD}^{+}$reduction and its ability to utilize both $\mathrm{NAD}^{+}$and $\mathrm{NADP}^{+}$ substrates. ${ }^{51}$ These measurements showed that the charcoal treatment produced $>90 \%$ of the enzyme in the 
apo-form. Apo-protein concentrations were determined by absorbances at $280 \mathrm{~nm}$ using the following absorptivities $\left(10^{5} \mathrm{M}^{-1} \mathrm{~cm}^{-1}\right)$ : phLDH 1.7, pmLDH 1.75, rmGAPDH 1.16, pmGAPDH 1.16, bsGAPDH 1.28, byGAPDH 1.3, rm $\alpha$ GHD 0.478, and phcMDH 0.32. Throughout this article, molar enzyme concentrations are given as those of the native oligomer, rather than subunit (binding site) concentrations. The molar absorptivities, pI, and molecular mass $\left(M_{r}\right)$ values were calculated using tools available on the Expasy website (http://www.expasy.ch as of 8/4/ 2005) from the sequences available at the National Center for Biotechnology Information (http://www.ncbi.nlm.nih. gov as of 8/4/2005); the calculated values adequately match the measured values that we were able to locate in the literature.

\section{Enzyme Assays}

Enzyme activities were measured by following absorbance at $340 \mathrm{~nm} .{ }^{51}$ Each activity measurement was repeated to establish reproducibility within $15 \%$. An enzyme unit (U) is defined herein as the amount of enzyme producing or using $1 \mu \mathrm{mol}$ of $\mathrm{NADH} / \mathrm{min}$ in the specified assay conditions. The molar absorptivity used for NADH was $6.22 \times 10^{3} \mathrm{M}^{-1} \mathrm{~cm}^{-1}$. For all assays, the buffer was Tris $/ \mathrm{HCl}, \mathrm{pH}=7.4,2 \mathrm{mM}$ EDTA and $1 \mathrm{mg} / \mathrm{mL}$ BSA to prevent enzyme denaturation due to absorption on the container surfaces or other deleterious reactions with protein binding denaturants. The total absorbance was recorded before each assay and the reaction rate was calculated from the initial velocity slopes (first 15\% of the total reactant concentration). For all GAPDH activity measurements, the assay mixture had $3 \mathrm{mM}$ 3-phosphoglycrate, $1 \mathrm{mM}$ ATP, $2 \mathrm{mM} \mathrm{MgCl}$, $10 \mathrm{U} / \mathrm{mL}$ of 3-phosphoglycerate kinase, and $100 \mu \mathrm{M}$ NADH. The specific activities measured for rmGAPDH or pmGAPDH were $94 \pm 10$ and $190 \pm 15 \mathrm{U} / \mathrm{mg}$ for bakers yeast GAPDH. All LDH assay mixtures were prepared with $630 \mu \mathrm{M}$ pyruvate, and 100 $\mu \mathrm{M}$ NADH. Specific activities of phLDH, pmLDH, and phcMDH were $130 \pm 15$ and $430 \pm 30$, and $430 \pm 40 \mathrm{U} / \mathrm{mg}$, respectively.

\section{Native Agarose Electrophoresis Experiments}

The buffer used for electrophoresis was $50 \mathrm{mM}$ MOPS/ $\mathrm{KOH}, \mathrm{pH}=6.9$, containing $1 \mathrm{mM}$ EDTA and 5-10 mM $\beta$-mercaptoethanol, hereafter called the "MOPS/KOH buffer." This buffer was used instead of the Tris/HCl buffer used for coprecipitation experiments to avoid development of $\mathrm{Cl}_{2}$ at the anode. The dialyzed enzyme solutions $(20 \mu \mathrm{L})$ containing $10 \%$ glycerol were loaded into the gel wells. Enzyme concentrations and quantities loaded are specified in the figure legends. Electrophoresis was performed at 70 $\mathrm{V}$ with $20 \mathrm{~cm}$ between the electrodes for about 4 to $5 \mathrm{~h}$ (run time was optimized to provide the best chance to see the shifts in electrophoretic mobility). Electrophoresis was performed in a cold room, which kept the temperature of the gel buffer at $8^{\circ} \mathrm{C}$ or lower. The buffer was circulated between anode and cathode compartments to prevent formation of ion gradients, which can distort protein migrations. The enzymes were detected by Coomassie Blue staining.

\section{Coprecipitation Measurements in the Presence of Polyethylene Glycol 6000}

The enzymes were prepared in $50 \mathrm{mM}$ Tris/ $\mathrm{HCl}, \mathrm{pH}=$ 7.4, $1 \mathrm{mM}$ EDTA, 5-10 mM $\beta$-mercaptoethanol and 10\% (w/v) concentration of PEG 6000. The samples were incubated on ice for $15 \mathrm{~min}$, and the insoluble and soluble proteins were separated by centrifugation for $12 \mathrm{~min}$ at $4^{\circ} \mathrm{C}$ and $16,000 \times g$. The extent of protein insolubility was calculated by measuring protein activities in the pellets and the supernatant. To evaluate whether enzyme denaturation occurred during the experiment, we compared the sum of enzymatic activities measured in the pellets and the supernatant with the activity measured at the start of the experiment.

The optimal PEG concentration was determined empirically by measuring solubility of individual proteins and coprecipitation in the mixture in the presence of 6 to $18 \%$ $\mathrm{w} / \mathrm{v}$ of PEG 6000 . We found that $10 \% \mathrm{w} / \mathrm{v}$ PEG 6000 gave the most favorable ratio between precipitation of individual proteins (rmGAPDH and $\mathrm{pmLDH}$ ) and coprecipitation of protein complexes. The protein concentration was kept low at $1.0 \mathrm{mg} / \mathrm{mL}$ to minimize the chances of nonspecific interaction. For consistency in comparisons with literature data, the buffer was chosen to be the same as the buffer $(50 \mathrm{mM}$ Tris/HCl $\mathrm{pH}=7.4,2 \mathrm{mM}$ EDTA, $5 \mathrm{mM}$ $\beta$-mercaptoethanol) used in earlier studies of functional interaction between $\mathrm{NAD}(\mathrm{H})$ dehydrogenases. ${ }^{38,40,41,46}$

\section{Sedimentation Velocity AUC Experiments}

We used a Beckman XL-A instrument, An-60-Ti rotor, and three sample cells with quartz windows and charcoalepon centerpieces with two sectors (12 mm optical path length). For each cell the enzyme samples $(1 \mathrm{mg} / \mathrm{mL}$ or 6.9 $\mu \mathrm{M})$ were loaded in one sector and PEG-buffer in another. Two cells had individual enzymes, and the third cell had the enzyme mixture at the same loading concentration. The AUC measurements were performed in the same conditions as the coprecipitation experiments except that sedimentation profiles were measured at $20 \pm 0.2^{\circ} \mathrm{C}$. The higher temperature was used to decrease solution viscosity and shorten the long sedimentation process in the PEG solutions. The temperature difference partially affects the extent of coprecipitation. The experiments started with the prescans at $3000 \times g$, and the sum of absorbances of the individual enzymes was compared to the absorbance of the mixture. From this comparison, we judge that $10 \%$ of each enzyme coprecipitated in the absence of salt and no coprecipitation was observed in the presence of salt. All insoluble proteins precipitate during the prescans, and the sedimentation profiles of soluble components were recorded at $40,000 \times g$, for $7 \mathrm{~h}$, with scans every $15 \mathrm{~min}$ for experiments without salt, and $12 \mathrm{~min}$ for experiments with $100 \mathrm{mM}$ NaCl. All sedimentation profiles were collected as a single scan with radial increments of $30 \mu \mathrm{m}$.

Because the molecular weights and sedimentation parameters for rmGAPDH and phLDH are essentially the same, we could use the self-association feature in the SEDFIT program ${ }^{52}$ to simulate sedimentation profiles that can be expected if a small fraction of the two- 
TABLE I. Best Fit for Sedimentation Velocity AUC Experiments in PEG Solution

\begin{tabular}{|c|c|c|c|}
\hline & $\begin{array}{c}10^{-3} \text { Buoyant } \\
\text { Molar Mass }\end{array}$ & S S & RMSD \\
\hline \multicolumn{4}{|l|}{$\mathrm{No} \mathrm{NaCl}$} \\
\hline phLDH alone & $25.0 \pm 0.1$ & $1.598 \pm 0.001$ & 0.0162 \\
\hline rmGAPDH & $26.3 \pm 0.02$ & $1.576 \pm 0.002$ & 0.0140 \\
\hline Mixture, no association & [25.9] & [1.58] & 0.0244 \\
\hline Mixture, $11 \%$ association & [25.9] & [1.58] & 0.0793 \\
\hline \multicolumn{4}{|l|}{$100 \mathrm{mM} \mathrm{NaCl}$} \\
\hline phLDH & $27.4 \pm 0.2$ & $2.595 \pm 0.002$ & 0.0131 \\
\hline rmGAPDH alone & $27.8 \pm 0.2$ & $2.525 \pm 0.002$ & 0.0093 \\
\hline Mixture, no association & [27.9] & {$[2.55]$} & 0.0390 \\
\hline Mixture, $11 \%$ association & [27.9] & {$[2.55]$} & 0.0508 \\
\hline
\end{tabular}

The sedimentation profiles were analyzed using SVEDBERG ${ }^{59}$ and SEDFIT $^{52}$ programs. The calculated $s$ and $D$ sedimentation parameters represent the buoyant mass measured in the PEG solution. The buoyant mass is defined as: $M_{b} \equiv R T s / D=M_{r}(1-v)$, where $M_{r}$ is the actual mass, $\rho$ is the solution density, $v$ is the partial specific volume, $R$ is the universal gas constant, $T$ is absolute temperature. We present buoyant mass because PEG solutions have different density and viscosity then the routinely used buffers. The values shown in square brackets were kept fixed in simulations of sedimentation profiles that correspond to different extent of interaction between the soluble proteins (see Methods). SS = sum of squares; RMSD = root-meansquare-deviations.

protein complex is soluble. We set the molar heteroassociation constant, $K_{a}^{M \text {, ha }}$ to a mathematically equiva-

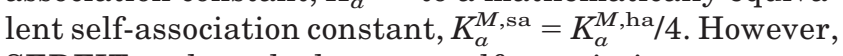
SEDFIT only calculates a self-association constant, $K_{\alpha}{ }^{\text {Ab,sa }}$ based, in our case, on total absorbance (Ab). The molar and absorbance constants are related by $K_{a}{ }^{\mathrm{M}, \text { ha }}=$ $K_{a}^{\mathrm{Ab} \text {,ha }}\left(\epsilon_{\mathrm{A}} \times \epsilon_{\mathrm{B}} \times b / \epsilon_{\mathrm{AB}}\right)$, where $b$ is the optical pathlength $(1.2 \mathrm{~cm}), \Sigma=2 \epsilon_{\text {avg }}$ is the molar absorptivity of the AB complex and $\Sigma_{\alpha \Omega \gamma}$ the average molar absorptivity of the two proteins. We chose $K_{a}^{M . h a}=1.77 \times 10^{4} \mathrm{M}^{-1}$, which corresponds to an $11 \%$ association of the enzymes at the loading concentration of $1 \mathrm{mg} / \mathrm{mL}$ each. Thus, a $K_{a}{ }^{\mathrm{Ab} \text {,sa }}=0.0532$ was used as a fixed variable in SEDFIT to assess the quality of fit assuming an $11 \%$ association of the enzymes at their loading concentrations (each at $6.9 \mu \mathrm{M})$.

The strategy was to calculate the best-fit RMSD with SEDFIT when fixing the $s$ and $D$ values to those in Table I, and assuming first, no hetero-association $\left(K_{a}^{\mathrm{Ab} \text {,sa }}=10^{-20}\right)$, and an association constant $\left(K_{a}{ }^{\mathrm{Ab} \text {,sa }}=0.0532\right)$ corresponding to an $11 \%$ association of each enzyme at the loading concentration of $1 \mathrm{mg} / \mathrm{mL}$. The hetero-association constant for this $11 \%$ association is $K_{\alpha}^{\mathrm{M} \text {,ha }}=1.77 \times 10^{4} \mathrm{M}^{-1}$. These two fits converged rapidly with the RMSD values specified in Table I. Plots of experimental and best-fit sedimentation profiles are shown for both the nonassociating [Fig. 7(A)] and $11 \%$ associating cases [Fig. 7(B)] under salt-free conditions. Similar plots were also generated for the 100 $\mathrm{mM} \mathrm{NaCl}$ data set. The consequence of assuming higher than 1:1 stoichiometry for the solution phase heterocomplex, would be even larger disparities between experimental and best-fit curves, because the $s$ values of such complexes would be larger than that assumed for the 1:1 complex.

\section{Molecular Modeling}

The program GRASP ${ }^{53}$ was used to calculate surface electrostatic potentials on the solvent-accessible protein surface, with all other parameters set at the program's default values (zero ionic strength, normal states of ionization of amino acids at $\mathrm{pH} 7.0$ ).

\section{RESULTS \\ Mobility Shift Experiments in Native Agarose Electrophoresis [Figs. 1(A-B) and 2(A-B)]}

Native agarose electrophoresis experiments are uniquely suited for detection of delicate protein-protein interactions. The method allows exceptionally high protein concentration that is limited only by protein solubility during the gel loading. Electrophoresis experiments were used successfully in the past to demonstrate delicate interactions between mitochondrial enzymes. ${ }^{26,54,55}$ Protein electrophoretic mobility is determined by its mass-charge ratio and its shape. ${ }^{56}$ Thus, in case of interaction there is a shift in protein electrophoretic mobility in the presence of interacting protein relative to the mobility of the free protein. The interaction specificity is tested by replacing one of the interacting proteins with a protein that has very similar net charge, size, and the same loading concentration.

We used agarose electrophoresis experiments to test for interaction between rmGAPDH and phLDH [Fig. 1(A-B)] or pmLDH [Fig. 2(A-B)]. A clear shift in electrophoretic mobility is observed with rmGAPDH and phLDH [Fig. 1(A)]. The opposite net charge and a large electrophoretic mobility makes rmGAPDH and phLDH ideal for mobility shift experiments. In contrast, pmLDH and rmGAPDH have very similar net charge and very low electrophoretic mobility. Thus, the interaction can give only a small retardation in mobility of $\mathrm{rmGAPDH}$. The interaction specificity [Figs. 1(B) and 2(B)] was tested by replacing rmGAPDH $\left(\mathrm{pI}=8.4, M_{r}=142 \mathrm{kDa}\right)$ with rabbit muscle aldolase $\left(15 \mathrm{mg} / \mathrm{mL} ; \mathrm{pI}=8.2, M_{r}=156 \mathrm{kDa}\right)$, which is also a glycolytic enzyme. No shifts in electrophoretic mobility can be observed with rmALD and any of the two LDH isozymes. In summary, the mobility shifts experiments suggested that rmGAPDH and the two $\mathrm{LDH}$ isozymes (phLDH and pmLDH) have a specific interaction at high protein concentration.

\section{PEG Coprecipitation [Figs. 3(A-B) and 4]}

In parallel with agarose electrophoresis experiments we used PEG coprecipitation experiments to study interaction between rmGAPDH and the two LDH isozymes (phLDH and pmLDH). To some extent PEG can mimic the excluded volume effects present in living cells. ${ }^{4,9}$ PEG solutions lead to lower solubility of macromolecules ${ }^{57,58}$ and favors protein-protein interactions. ${ }^{4,9}$ Protein solubility in PEG solutions correlates with the protein size and the net charge,${ }^{57}$ so that associated proteins normally have significantly lower solubility than the individual proteins. ${ }^{20,21,57}$ Thus, it is sometimes possible to find PEG concentrations where individual proteins are soluble and coprecipitation is observed in the mixture of interacting proteins. ${ }^{20-25,57}$ 
A

B

\section{cathode}

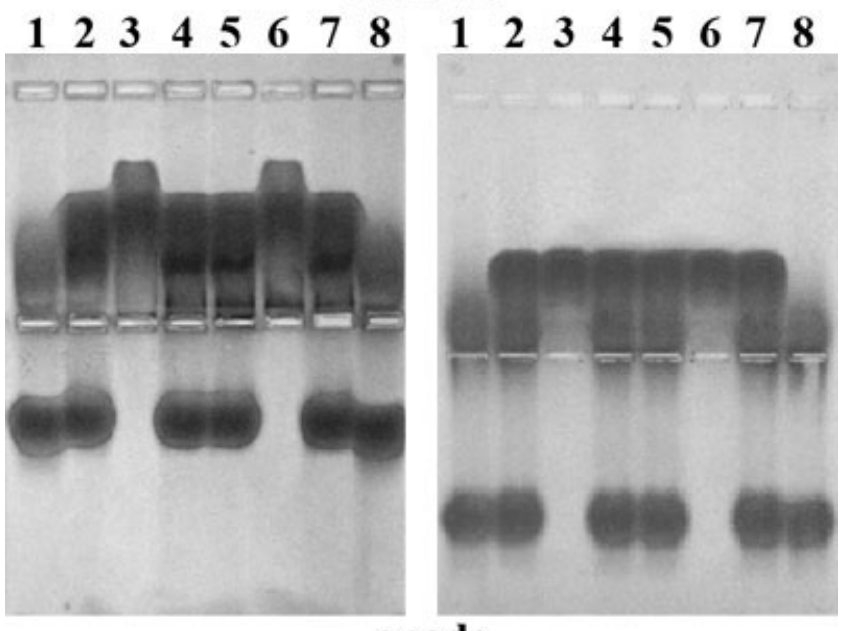

\section{anode}

Fig. 1. (A-B). Mobility shift experiment with phLDH and $r m G A P D H$ (A); control experiment with phLDH and rmALD (B). Lanes 1 and 8 contain only phLDH, lanes 3 and 6 contain only rmGAPDH, all other lanes contain both enzymes. The proteins were prepared in running buffer plus $10 \%$ glycerol; $20 \mu \mathrm{L}$ of phLDH (76 $\mu \mathrm{M}$ or $12 \mathrm{mg} / \mathrm{mL}$ ) was loaded at the cathode side, and $20 \mu \mathrm{L}$ of rmGAPDH $(104 \mu \mathrm{M}$ or $15 \mathrm{mg} / \mathrm{mL})$ was loaded in the middle. The electrophoresis run time was optimized to observe a maximal shift ( $\sim 4$ to $5 \mathrm{~h}$ ). phLDH moves from cathode to anode crossing the incoming front of rmGAPDH. The shift in electrophoretic mobility indicates interaction (lanes 2, 4, 5, and 7 vs. lanes 1 and 8 or lanes 3 and 6). (B) In the control experiment rmGAPDH ( $\mathrm{pl}=8.4, M_{\mathrm{r}}=142 \mathrm{kDa}$ ) was replaced with $\mathrm{rmALD}\left(15 \mathrm{mg} / \mathrm{mL}, \mathrm{pl}=8.2, M_{r}=156 \mathrm{kDa}\right)$ and all other conditions were kept the same. In all experiments the running buffer was $50 \mathrm{mM}$ MOPS $/ \mathrm{KOH} \mathrm{pH}=6.9,2 \mathrm{mM}$ EDTA, $5 \mathrm{mM} \beta$-mercaptoethanol. The temperature was controlled at $4-8^{\circ} \mathrm{C}$ and the electric field was 3.5 $\mathrm{V} / \mathrm{cm}$. The proteins were detected by coomassie staining. phLDH has two mobility fronts; the dominant first front corresponds to $\mathrm{H}_{4}$ tetrameter, and the lagging front corresponds to the $\mathrm{H}_{3} \mathrm{M}$ tetramer.

The specificity of PEG induced interaction can be tested by replacing one of the interacting proteins with another protein that has very similar net charge and size (i.e., pI and molecular mass).

We found that rmGAPDH and phLDH coprecipitate in the PEG solution with approximately 1:1 stoichiometry [Fig. 3, compare panels (A-B)]. Increasing concentration of phLDH $(0-14 \mu \mathrm{M}$ or $0-2 \mathrm{mg} / \mathrm{mL})$ was mixed in PEG solution with $\mathrm{rmGAPDH}(6.93 \mu \mathrm{M}$, or $1.0 \mathrm{mg} / \mathrm{mL})$. The coprecipitation was determined by measuring enzymatic activity of each protein [phLDH, Fig. 3(A); rmGAPDH, Fig. $4(\mathrm{~B})]$ in pellets and supernatant after centrifugation at $4^{\circ} \mathrm{C}$. phLDH is completely soluble in $10 \%$ (w/v) PEG 6000 solution in the absence of rmGAPDH. rmGAPDH is partially soluble; $30 \%$ of protein will precipitate in the absence of phLDH at starting concentration of $6.93 \mu \mathrm{M}(1.0$ $\mathrm{mg} / \mathrm{mL}$ ). That precipitation was subtracted as a background in the coprecipitation measurements. Two control measurements showed that coprecipitation is specific. First [Fig. 3(A)], phLDH did not precipitate in PEG solution when $6.93 \mu \mathrm{M} \mathrm{rmGAPDH}(142 \mathrm{kDa}, \mathrm{pI}=8.4)$ was replaced with $6.9 \mu \mathrm{M}$ rmALD $(156 \mathrm{kDa}, \mathrm{pI}=8.2)$. Second [Fig. 3(B)], rmGAPDH did not precipitate when increasing
A

B

\section{cathode}

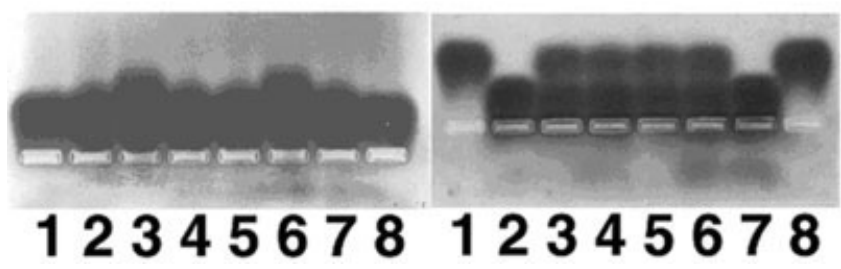

Fig. 2. (A-B). Mobility shift experiments with $\mathrm{pmLDH}$ and $\mathrm{rmGAPDH}$ (A); control experiment with pmLDH and rmALD (B). Lanes 1 and 8 contain only pmLDH $(62 \mu \mathrm{M}$ or $11 \mathrm{mg} / \mathrm{mL})$, lanes 3 and 6 contain only rmGAPDH (104 $\mu \mathrm{M}$ or $15 \mathrm{mg} / \mathrm{mL})$, and all other lanes have the two proteins together. The proteins were prepared in the running buffer plus $10 \%$ glycerol. Both proteins were loaded in the wells on the anode side of the gel (20 $\mu \mathrm{L}$ each) and migrate towards the cathode. The difference in mobility between free proteins and the protein mixture indicates interaction. (B) In a control experiment, rmGAPDH $\left(\mathrm{pl}=8.4 ; M_{r}=142 \mathrm{kDa}\right)$ is replaced by $\mathrm{rmALD}\left(\mathrm{pl}=8.2 ; M_{w}=156 \mathrm{kDa} ; 15 \mathrm{mg} / \mathrm{mL}\right)$, and all other conditions were kept the same. Lanes 1 and 8 contain only rmALD $(93 \mu \mathrm{M}$ or $15 \mathrm{mg} / \mathrm{mL})$, lanes 2 and 7 contain only pmLDH (62 $\mu \mathrm{M}$ or $11 \mathrm{mg} / \mathrm{mL})$, and all other lanes have both proteins. Both gels were run for $5 \mathrm{~h}$; the electric field was $3.5 \mathrm{~V} / \mathrm{cm}$, the buffer temperature was kept between $4-8^{\circ} \mathrm{C}$, and the buffer was $50 \mathrm{mM} \mathrm{MOPS} / \mathrm{KOH} \mathrm{pH}=6.9,2 \mathrm{mM}$ EDTA, 5 $\mathrm{mM} \beta$-mercaptoethanol.

concentration of phLDH $(144 \mathrm{kDa}, \mathrm{pI}=5.1)$ was replaced with increasing concentration of Bacillus stearothermophlus GAPDH (142 kDa, $\mathrm{pI}=4.8)$.

In comparison to phLDH, pmLDH $(144 \mathrm{kDa}, \mathrm{pI}=8.2)$ has very different net charge and solubility in PEG solution; $31-41 \%$ of pmLDH will precipitate in PEG solution at a starting concentration of $1.0 \mathrm{mg} / \mathrm{mL}(6.93$ $\mu \mathrm{M})$. Nevertheless, like phLDH, pmLDH coprecipitates with rmGAPDH with close to 1:1 stoichiometry (Fig. 4). PEG induced coprecipitation between pmLDH (144 kDa, $\mathrm{pI}=8.2)$ and rmGAPDH was measured by adding increasing concentrations of pmLDH $(0-8 \mu \mathrm{M}$ or $0-1.2 \mathrm{mg} / \mathrm{mL})$ to $6.93 \mu \mathrm{M}$ of rmGAPDH and vice versa. The coprecipitation was analyzed by measuring enzymatic activity of each protein (Fig. 4) in pellets and supernatant after centrifugation at $4^{\circ} \mathrm{C}$. In parallel with the coprecipitation experiment, we measured precipitation of individual proteins in PEG solution, and those values were subtracted as background. In the control experiment, precipitation of pmLDH was within experimental error close to background when $\mathrm{rmGAPDH}(142 \mathrm{kDa}, \mathrm{pI}=8.4)$ was replaced with $\operatorname{rmALD}(156 \mathrm{kDa}, \mathrm{pI}=8.2)$.

In summary, rmGAPDH can coprecipitate in PEG solution with phLDH or pmLDH, two proteins with very different net charge and solubility in PEG solution. No coprecipitation was observed when one of interacting proteins is replaced by another protein with very similar net charge and size. PEG insoluble proteins have full activity when resuspended in the absence of PEG, which indicates that PEG induced coprecipitation is not a result of protein denaturation. The coprecipitation between $\mathrm{rm}$ GAPDH and phLDH is not affected if $50 \mathrm{mM}$ Tris/HCl $\mathrm{pH}=7.4,1 \mathrm{mM}$ EDTA is replaced with the buffer that was used in the agarose electrophoresis experiments $(50 \mathrm{mM}$ MOPS/KOH, $\mathrm{pH}=6.9,1 \mathrm{mM}$ EDTA; Figs. 1 and 2). 

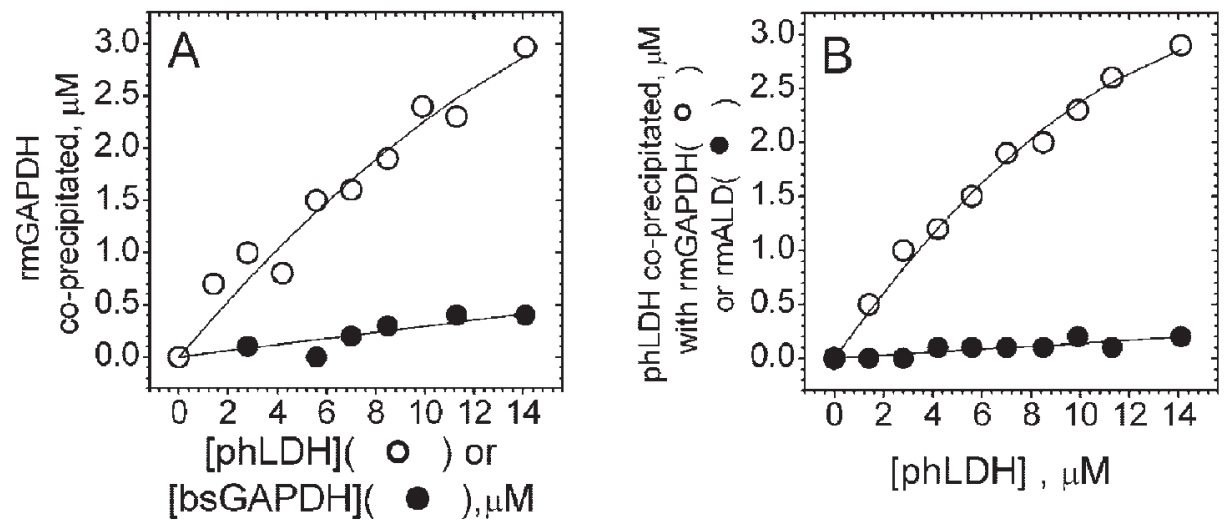

Fig. 3. (A-B). PEG induced coprecipitation between phLDH and rmGAPDH. (A) Coprecipitation of rmGAPDH (at fixed concentration $1.0 \mathrm{mg} / \mathrm{ml}, 6.9$ $\mu \mathrm{M})$ in the presence of variable concentration of phLDH $(\bigcirc)$ or $B$. Stearothermophlus (bsGAPDH) (O). (B) PEG-induced coprecipitations of phLDH (varying from 0 to $2 \mathrm{mg} / \mathrm{mL}, 0$ to $14 \mu \mathrm{M}$ ) in the presence of $1.0 \mathrm{mg} / \mathrm{mL}(6.9 \mu \mathrm{M})$ of rmGAPDH (O) or rmALD (๑). All experiments used $50 \mathrm{mM}$ Tris/HCl $\mathrm{pH}=7.4,1 \mathrm{mM}$ EDTA, $5 \mathrm{mM} \beta$-mercaptoethanol and $10 \%$ w/v of PEG 6000 .

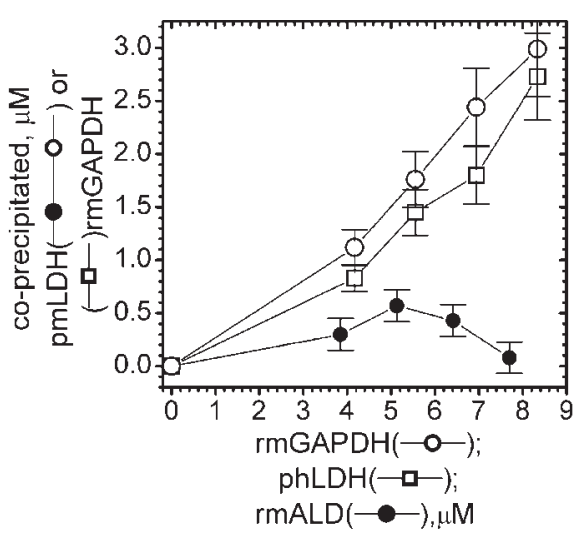

Fig. 4. PEG-induced coprecipitations between pmLDH and rmGAPDH. (O) Coprecipitation of pmLDH (varying from 0 to $1.2 \mathrm{mg} / \mathrm{mL}, 0$ to $8.3 \mu \mathrm{M}$ ) in the presence of rmGAPDH (fixed at $1.0 \mathrm{mg} / \mathrm{mL}, 6.9 \mu \mathrm{M}$ ). ( $\square$ ) Coprecipitation of rmGAPDH (varying from 0 to $1.2 \mathrm{mg} / \mathrm{mL}, 0$ to $8.3 \mu \mathrm{M}$ ) in the presence of pmLDH (fixed at $1.0 \mathrm{mg} / \mathrm{mL}, 6.9 \mu \mathrm{M}$ ). (๑) A control measurement; coprecipitation of pmLDH (fixed at $1.0 \mathrm{mg} / \mathrm{mL}, 6.9 \mu \mathrm{M}$ ) in the presence of rmALD (varying 0 to $1.2 \mathrm{mg} / \mathrm{mL}, 0$ to $7.8 \mu \mathrm{M}$ ). All experiments used $50 \mathrm{mM}$ Tris $/ \mathrm{HCl} \mathrm{pH}=7.4,1 \mathrm{mM}$ EDTA, $5 \mathrm{mM}$ $\beta$-mercaptoethanol and $10 \% \mathrm{w} / \mathrm{v}$ of PEG 6000 .

\section{Sedimentation Velocity AUC Experiments in the Presence of $10 \%$ w/v PEG 6000 [Fig. 5(A-D)]}

A PEG solution and the high protein concentration in vivo can favor protein-protein interaction, but those conditions can also lead to a decrease in protein solubility. ${ }^{57,58}$ Protein solubility in PEG solution correlates with its size and the net charge, ${ }^{57,58}$ so it could be expected that a PEG induced complex will have a significantly lower solubility than the individual components. For example, the PEGinduced complex between mitochondrial malate dehydrogenase and citrate synthase is completely insoluble. ${ }^{20}$ Nevertheless, such insoluble complex is active in substrate channeling, ${ }^{27}$ and substrate channeling is likely to exist between citrate synthase and malate dehydrogenase in living cells. ${ }^{17,18}$ We use sedimentation velocity AUC experiments to measure to what extent a PEG-induced complex between rmGAPDH and phLDH is soluble in PEG solution.
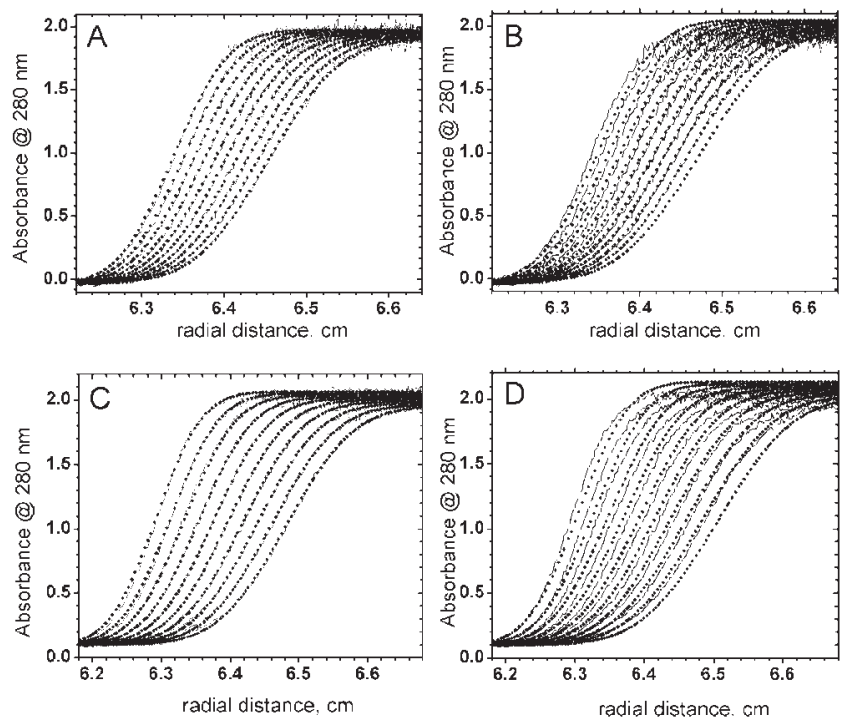

Fig. 5. (A-D). Sedimentation velocity profiles for phLDH and rmGAPDH in the presence of $10 \%(\mathrm{w} / \mathrm{v})$ PEG 6000 without $\mathrm{NaCl}(\mathbf{A}-\mathbf{B})$ and with $100 \mathrm{mM} \mathrm{NaCl}$ (C-D). (A-B) Selected sedimentation profiles for phLDH and rmGAPDH in $10 \%$ w/v PEG 6000 and $50 \mathrm{mM} \mathrm{Tris} / \mathrm{HCl} \mathrm{pH}=$ 7.4, $1 \mathrm{mM}$ EDTA-Na, $5 \mathrm{mM} \beta$-mercaptoethanol. The full line indicates the actual scans, and the dotted line indicates numerical simulation for no association (A), and $11 \%$ association (B), at the loading concentration of $6.9 \mu$ M. (C-D) Same as in (A-B), except that the buffer had $100 \mathrm{mM}$ $\mathrm{NaCl}$. In all four figures sedimentation was measured at $20 \pm 0.2^{\circ} \mathrm{C}$, $40,000 \times g$, for $7 \mathrm{~h}$, with the absorbance scans every 15 (A-B) or $12 \mathrm{~min}$ (C-D).

Sedimentation profiles for individual proteins and the two-protein mixture were measured in parallel using a rotor with three sample cells (see Methods). We first analyzed selected scans for individual proteins using the SVEDBERG $^{59}$ and SEDFIT ${ }^{52}$ programs. The two programs gave identical sedimentation parameters except for the difference in the statistics for the fit quality, which can be explained by different adjustable parameters used by each program. The fits converged readily (Table I) with small RMSD (Table I) and randomly distributed errors (not shown). Next, we analyzed the sedimentation profiles 
of rmGAPDH and phLDH mixture using a two-noninteracting species model. The fit was unsuccessful due to lack of conversion; which is understandable because phLDH and rmGAPDH have very similar sedimentation properties (Table I). Actually, the sedimentation profiles of the two protein mixture gave a good fit to the single species model [Fig. 5(A)]. A good fit to the single species model was the first indication that there is no higher molecular weight complex present as a soluble form in the PEG solution. In fact, the high similarity in the sedimentation parameters for phLDH and rmGAPDH (Table I) gave us a unique opportunity to use the self-association model in the SEDFIT program to simulate the sedimentation profiles that can be expected if a small fraction of soluble complex is present in PEG solution (see Methods). The clear difference between the actual sedimentation profiles and the profiles that simulate $11 \%$ association shows that it is very unlikely that even a small fraction of phLDH-rmGAPDH complex can exist as a soluble form in the PEG solution [Fig. 5(B)].

An increase in ionic strength generally leads to an increase in protein solubility in PEG solution. ${ }^{57,58}$ Indeed, we find that adding $100 \mathrm{mM} \mathrm{NaCl}$ will abolish the PEG induced precipitation of rmGAPDH, and the coprecipitation between rmGAPDH and phLDH. The AUC experiments showed that there is no soluble complex between phLDH and rmGAPDH in PEG solution in the presence of salt [Fig. 5(C-D)]. Thus, an increase in ionic strength leads to higher protein solubility in PEG solution, the absence of coprecipitation, and a breakup of the complex. All three observations can be attributed to a change in the physical properties of PEG solution caused by the addition of salt, as indicated by a change in the protein sedimentation parameters measured with and without the salt (Table I). A lack of a soluble complex in the presence of salt should not be misinterpreted as evidence that the complex cannot form at the higher ionic strength present in vivo. The extent to which an increase in ionic strength affects protein function and the excluded volume effect depends on ion type and on the reagent used to create the excluded volume effect. ${ }^{8}$ PEG cannot create exactly the same excluded volume effect as macromolecules at high concentration in vivo. ${ }^{8}$ Also, $\mathrm{Na}^{+}$and $\mathrm{Cl}^{-}$do not represent the complex ion mixture in cytoplasm. ${ }^{8}$

In summary, it appears that rmGAPDH and phLDH can form only an insoluble complex in PEG solution. It is possible that at high protein concentration in vivo those two proteins exist only as an insoluble complex. Many proteins are likely to be insoluble at exceptionally high protein concentrations present in vivo. ${ }^{1,3,8}$ In vivo, two proteins can interact by adsorption on cellular structures, ${ }^{30,31,37}$ while in the PEG coprecipitation experiments the initial PEG induced aggregates of rmGAPDH could trigger coadsorption of rmGAPDH and phLDH.

\section{PEG Coprecipitation in the presence of NADH and $\mathrm{NAD}^{+}$[Fig. 6(A-B)]}

Protein-protein interactions are often modulated by metabolites. ${ }^{22,38,55,60}$ The metabolite-mediated protein in-
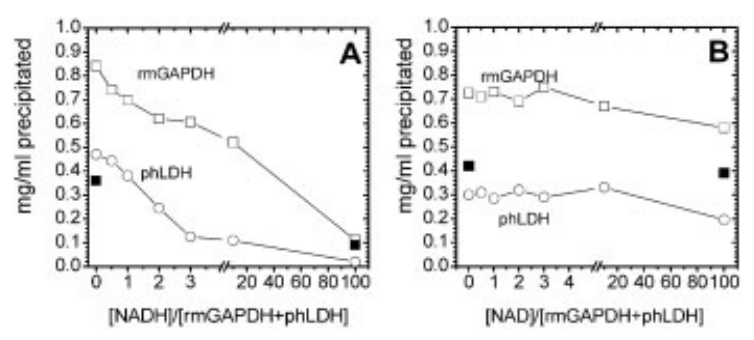

Fig. 6. (A-B). PEG-induced coprecipitation between phLDH $(\bigcirc)$ and rmGAPDH ( $\square$ ) in the presence of increasing concentration of NADH (A) or $\mathrm{NAD}^{+}(\mathrm{B})$. The background precipitation of rmGAPDH (i.e., precipitations in the absence of phLDH) is indicated in the figures ( $\square$ ) and not subtracted from the coprecipitation profiles $(O, \square)$. The concentration of each enzyme was kept fixed at $1.0 \mathrm{mg} / \mathrm{mL}(6.9 \mu \mathrm{M})$ for a total of $13.8 \mu \mathrm{M}$ native enzyme or $55.2 \mu \mathrm{M}$ coenzyme binding sites. All experiments used $50 \mathrm{mM}$ Tris $/ \mathrm{HCl} \mathrm{pH}=7.4,1 \mathrm{mM}$ EDTA, $5 \mathrm{mM} \beta$-mercaptoethanol and $10 \% \mathrm{w} / \mathrm{v}$ of PEG 6000.

teractions can be a metabolic control mechanism in vivo. We tested how $\mathrm{NAD}^{+}$and NADH affect the interaction between rmGAPDH and phLDH by measuring PEG induced coprecipitation in the presence of each cofactor. We found that PEG induced coprecipitation between rmGAPDH and phLDH can be easily abolished by saturation with $\mathrm{NADH}$, but not by saturation with $\mathrm{NAD}^{+}$[Fig. 6(A-B)]. Stoichiometric concentration of NADH will disrupt the coprecipitation [Fig. 6(A)], while $\mathrm{NAD}^{+}$does not affect the coprecipitation even when present in a 100-fold higher concentration [up to $1 \mathrm{mM}$; Fig. 6(B)]. NADH and $\mathrm{NAD}^{+}$differ in the net charge and have different binding properties with each enzyme. ${ }^{61-63}$ Interestingly in the absence of phLDH, rmGAPDH has different solubility in PEG solution in the presence of $\mathrm{NAD}^{+}$and NADH (Fig. 6). Thus, we propose that the difference in solubility of rmGAPDH in the presence of $\mathrm{NAD}^{+}$and NADH leads to the difference in PEG-induced coprecipitation between phLDH and rmGAPDH in the presence of each cofactor.

\section{Structural Studies of GAPDH Interaction with Two LDH Isozymes [Fig. 7(A-D)]}

A specific interaction between GAPDH and LDH isozymes means that those proteins have complementary surfaces that can support such interaction. There is extensive structural information on LDH and GAPDH enzyme families (Fig. 7). We used molecular modeling studies in search for complementary surface shape, electrostatic potentials, ${ }^{53}$ and overall symmetry between the tetramers of rmGAPDH and phLDH or pmLDH (Fig. 7). A similar study in the past showed that enzymes in the TCA cycle shared complementary surface potentials and topology that can support functional interaction in vivo ${ }^{64}$ In Figure 7(A), GAPDH tetramer is shown with its crystallographic $\mathrm{R}$ and $\mathrm{Q}$ axis $^{65}$ in the plane of the paper facing phLDH tetramer with its crystallographic $\mathrm{P}$ and $\mathrm{Q}$ axis $^{66}$ parallel with the plane of the paper. The docked models show complementary size, symmetry, and surface topology, with two subunits interfaced below the plane of paper, and two subunits interfaced above the plane of the paper [Fig. 7(A)]. A closer examination shows that interacting sub- 


\section{A}
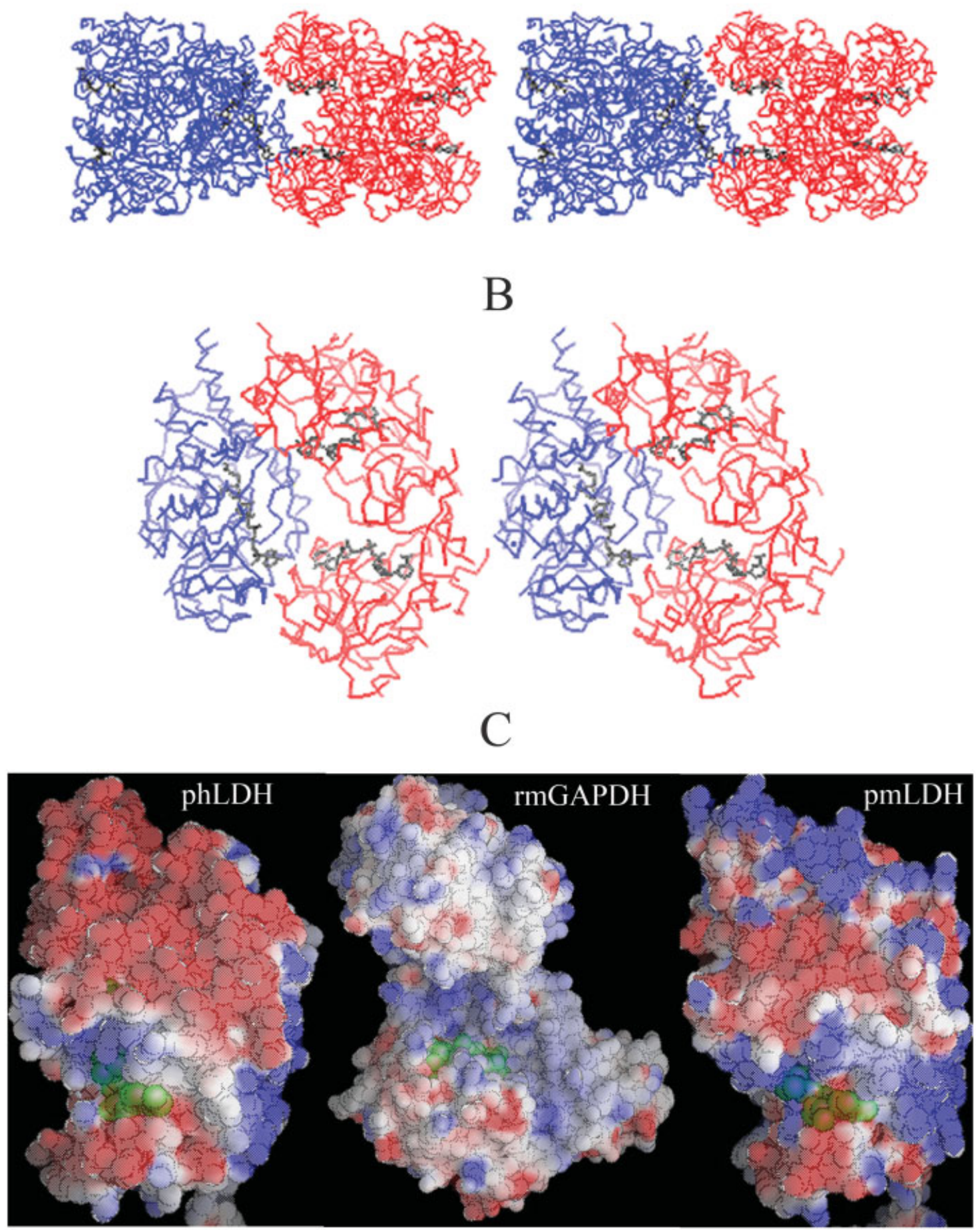

Fig. 7. (A-C). Molecular modeling studies of interaction between rmGAPDH and two LDH isozymes (Brookhaven Protein Data Bank: phLDH, $5 \mathrm{LDH} ;{ }^{66} \mathrm{pmLDH}, 9 \mathrm{LDT} ;{ }^{73}$ and rmGAPDH, $1 \mathrm{j0} \mathrm{x}^{65}$ ). (A) A stereoview of phLDH tetramer (blue) facing rmGPADH tetramer (red) based on complementary shapes and symmetry. rmGAPDH is shown with its crystallographic $R$ and $Q$ axis ${ }^{65}$ in the plane of the paper facing phLDH with its crystallographic $P$ and $\mathrm{Q}$ axis ${ }^{66}$ roughly parallel to the plane of the paper. $\mathrm{NAD}^{+}$molecules are shown in black to indicate $\mathrm{NAD}^{+}$binding sites. For better orientation we have inserted two NAD ${ }^{+}$molecules in the $\mathrm{O}$ and $\mathrm{Q}$ subunits of rmGAPDH using structural similarities between rabbit and human enzyme. ${ }^{74}$ (B) A stereoview of a closeup of the interface between phLDH (blue) and rmGAPDH (red) as shown in (A). (C) Electrostatic potentials $\left(\right.$ GRASP $\left.{ }^{53}\right)$ surrounding the NAD(H) binding site for phLDH (left, scale $\pm 4 k_{B} T / e$ ), rmGAPDH (middle, scale $\pm 10 k_{B} T / e$ ), and pmLDH (right, $\pm 4 k_{B} T / e$ ). The surface potential is proportional to the color intensity: negative potentials, red, and positive potentials, blue. The surface potentials on the solvent-accessible surface are shown "transparent" so that it is possible to see solvent exposed parts of bound NAD ${ }^{+}$(green). The enzymes are shown with their suggested docking surfaces facing the reader. GAPDH is shown with its $N A D(H)$ binding cavity facing the reader and its $\mathrm{R}$ axis perpendicular to the plane of paper. For better resolution only one subunit of each LDH isozyme is shown and GAPDH is shown as a dimer (P and Q subunits) as indicated in the text. Thus, the GAPDH model is shown about two times smaller than the LDH models. 
units form a partially secluded cavity between the two $\mathrm{NAD}(\mathrm{H})$ binding sites [Fig. 7(B)].

Next, we have analyzed complementary electrostatic potentials around the proposed docking surfaces [Fig. 7(C)]. GAPDH is shown as a dimer [Fig. 7(A)], because $\mathrm{NADH}$ binding sites are buried in the cofactor binding cavity between the two subunits [Fig. 7(B)] and not readily accessible for interaction with other proteins. Looking down the crystallographic $\mathrm{R}$ axis into the NADH binding cavity, we found that the surface outlining the cavity has predominantly positive potential [Fig. 7(C); the scale was adjusted to $\pm 10 k_{B} T / e$, where $k_{B}=1.38110^{-23} \mathrm{~J} / \mathrm{K}, T=$ $278 \mathrm{~K}, e=1.6022 \times 10^{-19} \mathrm{C}$ ). As a result, there is also a uniform positive potential in the space that fills the cofactor binding cavity [Fig. 7(A-B)].

$\mathrm{LDH}$ subunits are predominantly $\mathrm{H}$ form in heart and predominantly $\mathrm{M}$ form in smooth and skeletal muscle. ${ }^{62}$ Interestingly, even though heart and muscle isozymes have very different $\mathrm{pI}$ and kinetic properties, ${ }^{62}$ the surface surrounding the $\mathrm{NAD}(\mathrm{H})$ binding site is conserved between the two forms. ${ }^{67}$ In both forms the protein surface surrounding the NADH binding site has no charged amino acids, ${ }^{67}$ the surface potential is weak, and clear patches can be seen only when the scale is adjusted to $\pm 4 k_{B} T / e$ [Fig. 7(C)]. Nevertheless, the resulting surface clearly shows a predominantly negative electrostatic potential separated by a trace of neutral and positive potential. The trace of positive potential corresponds to the binding site for the two negatively charged phosphate groups on $\mathrm{NAD}(\mathrm{H})$. Those phosphate groups were not included in the calculation shown in the Figure 7(C). However, when the phosphate groups from bound $\mathrm{NAD}(\mathrm{H})$ are included in calculation, the surface surrounding the $\mathrm{NAD}(\mathrm{H})$ binding site has a uniform negative potential on both $\mathrm{LDH}$ isozymes. The negative potential on $\mathrm{LDH}$ isozymes complements the positive potential in the space that fills the cofactor binding cavity of rmGAPDH.

\section{DISCUSSION}

GAPDH and LDH are part of the glycolytic pathway, the major metabolic pathway that provides cells with metabolic precursors and a rapid source of energy. Combined action of GAPDH and $\mathrm{LDH}$ is crucial for maintaining a healthy balance between glycolysis and the cytosolic $\mathrm{NAD}^{+}$/ $\mathrm{NADH}$ pool. The cytosolic $\mathrm{NAD}^{+} / \mathrm{NADH}$ pool can also affect cellular respiration and the mitochondrial $\mathrm{NAD}^{+} /$ NADH pool, ${ }^{49}$ and cellular anabolic processes that depend on $\mathrm{NADP}^{+} / \mathrm{NADPH}$ pool (i.e., malate dehydrogenase isozymes). The three pools are highly unequilibrated, ${ }^{68}$ with cytosolic $\left[\mathrm{NAD}^{+}\right] /[\mathrm{NADH}]=700$, cytosolic $\left[\mathrm{NADP}^{+}\right] /$ $[\mathrm{NADPH}]=0.1$, and mitochondrial $\left[\mathrm{NAD}^{+}\right] /[\mathrm{NADH}]=$ 0.1 . The mechanism and the extent of communication between the different $\mathrm{NAD}(\mathrm{H})$ and $\operatorname{NADP}(\mathrm{H})$ pools is not known; however, there is no doubt that the connection between different pools is a vital part of cell physiology and tumor development. ${ }^{69}$ GAPDH is the most abundant glycolytic enzyme, and the most abundant NADH dehydrogenase in cytosol. ${ }^{33}$ In that context it is not surprising that GAPDH affects cell physiology far beyond its catalytic role as a glycolytic enzyme (reviewed by Sirover ${ }^{32}$ ). Several studies indicated that GAPDH binds to cytoskeletal networks and cellular membranes together with other glycolytic enzymes. ${ }^{29,36,37}$ An assembly between glycolytic enzymes is also often debated, ${ }^{37}$ because its molecular mechanism and the functional consequences are not fully understood. In this study we show that mammalian GAPDH can interact with $\mathrm{LDH}$ isozymes from heart and muscle. This conclusion is consistent with recent in vivo studies that suggested that in red blood cells LDH could bind cell membranes through GAPDH. ${ }^{37}$

Interaction between GAPDH and two $\mathrm{LDH}$ isozymes further supports earlier proposals ${ }^{49}$ that there is some degree of separation between glycolysis and cellular $\mathrm{NAD}^{+}$/ $\mathrm{NADH}$ pool. How interaction between GAPDH and two $\mathrm{LDH}$ isozymes affects kinetic properties of each enzyme has to be described in a separate manuscript (Svedružić et al., in preparation). Briefly, it has been suggested that there is $\mathrm{NAD}(\mathrm{H})$ channeling ${ }^{38,40,41}$ between cytosolic and mitochondrial $\mathrm{NAD}(\mathrm{H})$ dehydrogenases of opposite chiral specificity. ${ }^{42}$ However, some of the channeling results have been extensively debated. ${ }^{43-48}$ One of the criticisms of NADH channeling is the absence of detectable complex between $\mathrm{NAD}(\mathrm{H})$ dehydrogenases. ${ }^{46-48}$ Accordingly, this study can be one of the missing links in the $\mathrm{NAD}(\mathrm{H})$ channeling debate.

The presented interaction between GAPDH and two $\mathrm{LDH}$ isozymes is specific: (1) the interaction was observed using two independent methods, PEG coprecipitation and native agarose electrophoresis; (2) rmGAPDH associates with two $\mathrm{LDH}$ isozymes that have very different net charge and solubility in PEG solution, while no interaction was observed when one of interacting enzymes is replaced by another protein with closely similar size and the net charge; (c) the interaction can be broken by micromolar concentration of common ligand $\mathrm{NADH}$; (4) no interaction can be detected between mammalian $\mathrm{LDH}$ isozymes and GAPDH from other species even though GAPDH enzymes from different species share more than 55\% sequence identity and a highly conserved backbone fold (see the next paragraph).

Like rmGAPDH, porcine muscle GAPDH (pmGAPDH) shows PEG induced coprecipitation with phLDH and pmLDH. This is not surprising, because a sequence alignment shows that rabbit and porcine GAPDH share $96.5 \%$ sequence identity. ${ }^{70}$ We chose to work with rmGAPDH, rather than pmGAPDH, because rmGAPDH is more readily accessible and better described in the literature. ${ }^{61,65} \mathrm{Mam}-$ malians have only one GAPDH isozyme in different organs. ${ }^{71}$ The structure of $\mathrm{NAD}(\mathrm{H})$ binding domain in $\mathrm{NAD}(\mathrm{H})$ dependent dehydrogenases is highly conserved. ${ }^{71}$ Thus, we analyzed interaction between other $\mathrm{NAD}(\mathrm{H})$ dehydrogenases of opposite chiral specificity ${ }^{42}$ using PEG coprecipitation and agarose electrophoresis experiments. We find no interaction between phLDH and rabbit muscle glycerol-3-phosphate dehydrogenase, bakers yeast GAPDH, or Bacillus stearothermophlus GAPDH (bsGAPDH). No interaction was observed in the same experiments if phLDH was replaced with pmLDH, or porcine heart 
mitochondrial or cytosolic malate dehydrogenase. In summary, the PEG coprecipitation, and the agarose mobility shift experiments did not show interaction between different NADH dehydrogenases even though those enzymes have a highly conserved backbone fold and sometimes more than $50 \%$ sequence identity (e.g., rmGAPDH vs. bakers yeast GAPDH, or Bacillus stearothermophilus GAPDH). Another study from our group showed that the earlier reported high affinity interaction $\left(K_{d} \sim 1 \mu \mathrm{M}\right)$ between mammalian glycerol-3-phosphate dehydrogenase and lactate dehydrogenase is not valid. ${ }^{72}$ Thus, if there is a functional interaction between different $\mathrm{NAD}(\mathrm{H})$ dehydrogenases in living cells ${ }^{33,49}$ it is very likely that such interactions can be difficult to detect with purified proteins. Similar conclusion came from studies of functionally interactions between mitochondrial enzymes in TCA cycle. $^{16}$

\section{ACKNOWLEDGMENTS}

We thank Allen Minton at NIH for his kind invitation for H.O.S. to visit his lab, and to him and his assistant, David Hillar, for their assistance in performing an equilibrium and sedimentation velocity experiment on solutions of phLDH, rm- and by-GAPD similar to the ones described herein. We also thank our previewers, Christopher Mathews, Adrian Elcock, Harvey Knull, Allen Minton, Christopher H. Chang, and Chad Bjorklund for their patience and excellent recommendations.

\section{REFERENCES}

1. Srere PA. Protein Crystals as a model for mitochondrial matrix proteins. Trends Biochem Sci 1981;6:4-6.

2. Goodsell DS. Inside a living cell. Trends Biochem Sci 1991;16:203206.

3. Clegg SJ. Cellular infrastructure and metabolic organization. In: Stadtman ER, Chock PB, editors. From metabolite, to metabolism, to metabolon. Volume 33, current topics in cellular regulation. New York: Academic Press; 1992. p 3-15

4. Zimmerman SB, Minton AP. Macromoleculare crowding: biochemical, biophysical, and physiological consequences. Annu Rev Biophys Biomol Struct 1993;22:27-65.

5. Srere PA. Enzyme concentrations in tissues. Science 1967;158:936937.

6. Srere PA. Is there an organization of krebs cycle enzymes in the mitochondrial matrix? In: Mehlman MA, Hanson RW, editors. Energy metabolism and the regulation of metabolic processes in mitochondria. New York: Academic Press; 1972. p 79-91.

7. Berg OG. Influence of macromolecular crowding on thermodynamic activity: solubility and dimerisation constants for spherical and dumbbell-shaped molecules in a hard-sphere mixture. Biopolymers 1990;30:1027-1037.

8. Garner MM, Burg MB. Macromolecular crowding and confinement in cells exposed to hypertonicity. Am J Physiol 1994;266: C877-C892.

9. Minton AP. Implications of macromolecular crowding for protein assembly. Curr Opin Struct Biol 2000;10:34-39.

10. Lerman LS. Physico-chemical properties of the nucleic acids. In: Duchesne J, editor. Physico-chemical properties of the nucleic acids. New York: Academic Press; 1973.

11. Srere PA. Macromolecular interactions: tracing the roots. Trends Biochem Sci 2000;25:150-153.

12. Nooren IM, Thornton JM. Diversity of protein-protein interactions. EMBO J 2003;22:3486-3492.

13. Srere PA, Mathews CK. Purification of multienzyme complexes. Methods Enzymol 1990;182:539-551.

14. Ovadi J. Physiological significance of metabolite channeling. J Theor Biol 1991;152:1-22.
15. Srere PA. Complexes of sequential metabolic enzymes. Annu Rev Biochem 1987;56:89-124.

16. Srere PA. 17th Fritz Lipmann lecture. Wanderings (wonderings) in metabolism. Biol Chem Hoppe Seyler 1993;374:833-842.

17. Sumegi B, McCammon MT, Sherry AD, Keys DA, McAlister-Henn L, Srere PA. Metabolism of [3-13C]pyruvate in TCA cycle mutants of yeast. Biochemistry 1992;31:8720-8725.

18. Sumegi B, Sherry AD, Malloy CR, Srere PA. Evidence for orientation-conserved transfer in the TCA cycle in Saccharomyces cerevisiae: ${ }^{13} \mathrm{C}$ NMR studies. Biochemistry 1993;32:12725-12729.

19. Kispal G, Evans CT, Malloy C, Srere PA. Metabolic studies on citrate synthase mutants of yeast. A change in phenotype following transformation with an inactive enzyme. J Biol Chem 1989;264: 11204-11210.

20. Merz JM, Webster TA, Appleman JR, Manley ER, Yu HA, Datta A, Ackerson BJ, Spivey HO. Polyethylene glycol-induced heteroassociation of malate dehydrogenase and citrate synthase. Arch Biochem Biophys 1987;258:132-142.

21. Halper LA, Srere PA. Interaction between citrate synthase and mitochondrial malate dehydrogenase in the presence of polyethylene glycol. Arch Biochem Biophys 1977;184:529-534.

22. Fahien LA, Kmiotek EH, MacDonald MJ, Fibich B, Mandic M. Regulation of malate dehydrogenase activity by glutamate, citrate, alpha-ketoglutarate, and multienzyme interaction. J Biol Chem 1988;263:10687-10697.

23. Fahien LA, Kmiotek E, Smith L. Glutamate dehydrogenasemalate dehydrogenase complex. Arch Biochem Biophys 1979;192: 33-46.

24. Fahien LA, Kmiotek E. Precipitation of complexes between glutamate dehydrogenase and mitochondrial enzymes. J Biol Chem 1979;254:5983-5990.

25. Fahien LA, MacDonald MJ, Teller JK, Fibich B, Fahien CM. Kinetic advantages of hetero-enzyme complexes with glutamate dehydrogenase and the alpha-ketoglutarate dehydrogenase complex. J Biol Chem 1989;264:12303-12312.

26. Ashmarina LI, Pshezhetsky AV, Spivey HO, Potier M. Demonstration of enzyme associations by countermigration electrophoresis in agarose gel. Anal Biochem 1994;219:349-355.

27. Datta A, Merz JM, Spivey HO. Substrate channeling of oxalacetate in solid-state complexes of malate dehydrogenase and citrate synthase. J Biol Chem 1985;260:15008-15012.

28. Lindbladh C, Rault M, Hagglund C, Small WC, Mosbach K, Bulow L, Evans C, Srere PA. Preparation and kinetic characterization of a fusion protein of yeast mitochondrial citrate synthase and malate dehydrogenase. Biochemistry 1994;33:11692-11698.

29. Knull HR, Walsh JL. Association of glycolytic enzymes with the cytoskeleton. Curr Top Cell Regul 1992;33:15-30.

30. Walsh JL, Knull HR. Heteromerous interactions among glycolytic enzymes and of glycolytic enzymes with F-actin: effects of poly(ethylene glycol). Biochim Biophys Acta 1988;952:83-91.

31. Walsh JL, Keith TJ, Knull HR. Glycolytic enzyme interactions with tubulin and microtubules. Biochim Biophys Acta 1989;999: 64-70.

32. Sirover MA. New insights into an old protein: the functional diversity of mammalian glyceraldehyde-3-phosphate dehydrogenase. Biochim Biophys Acta 1999;1432:159-184.

33. Srivastava DK, Bernhard SA. Biophysical chemistry of metabolic reaction sequences in concentrated enzyme solution and in the cell. Annu Rev Biophys Biophys Chem 1987;16:175-204.

34. Nygaard AP, Rutter WJ. Interaction of pyridine-nucleotide linked enzymes. Acta Chem Scand 1956;10:37-48.

35. Cori CF, Velick SF, Cori GT. The combination of diphosphopyridine nucleotide with glyceraldehyde phosphate dehydrogenase. Biochim Biophys Acta 1950;4:160-169.

36. Muronetz VI, Shcherbatova NA, Nagradova NK. Interaction of NAD-dependent dehydrogenases with human erythrocyte membranes. Evidence that D-glyceraldehyde-3-phosphate dehydrogenase and lactate dehydrogenase are catalytically active in a membrane-bound state. Appl Biochem Biotechnol 1996;61:39-46.

37. Campanella ME, Chu H, Low PS. Assembly and regulation of a glycolytic enzyme complex on the human erythrocyte membrane. Proc Natl Acad Sci USA 2005;102:2402-2407.

38. Fukushima T, Decker RV, Anderson WM, Spivey HO. Substrate channeling of NADH and binding of dehydrogenases to complex I. J Biol Chem 1989;264:16483-16488.

39. Grandier-Vazeille X, Bathany K, Chaignepain S, Camougrand N, Manon S, Schmitter JM. Yeast mitochondrial dehydrogenases are 
associated in a supramolecular complex. Biochemistry 2001;40: $9758-9769$.

40. Ushiroyama T, Fukushima T, Styre JD, Spivey HO. Substrate channeling of $\mathrm{NADH}$ in mitochondrial redox processes. In: Stadtman ER, Chock PB, editors. From metabolite, to metabolism, to metabolon. Volume 33, current topics in cellular regulation. New York: Academic Press; 1992. p 291-307.

41. Srivastava DK, Bernhard SA. Mechanism of transfer of reduced nicotinamide adenine dinucleotide among dehydrogenases. Biochemistry 1985;24:623-628.

42. You KS. Stereospecificity for nicotinamide nucleotides in enzymatic and chemical hydride transfer reactions. CRC Crit Rev Biochem 1985; 17:313-451.

43. Srivastava DK, Smolen P, Betts GF, Fukushima T, Spivey HO, Bernhard SA. The direct transfer of NADH between $\alpha$-glycerol phosphate dehydrogenase and lactate dehydrogenase. Fact or misinterpretation? Proc Natl Acad Sci USA 1989;86:6464-6468.

44. Wu XM, Gutfreund H, Chock PB. Kinetic method for differentiating mechanisms for ligand exchange reactions: application to test for substrate channeling in glycolysis. Biochemistry 1992;31:21232128.

45. Spivey HO. Evidence of NADH channeling between dehydrogenases. J Theor Biol 1991;152:103-107.

46. Wu X, Gutfreund H, Lakatos S, Chock PB. Substrate channeling in glycolysis: a phantom phenomenon. Proc Natl Acad Sci USA 1991;88:497-501.

47. Brooks SP, Storey KB. Re-evaluation of the glycerol-3-phosphate dehydrogenase/L-lactate dehydrogenase enzyme system. Evidence against the direct transfer of $\mathrm{NADH}$ between active sites. Biochem J 1991;278(Pt 3):875-881.

48. Keizer J, Smolen P. Mechanisms of metabolite transfer between enzymes: diffusional versus direct transfer. Curr Top Cell Regul 1992;33:391-405.

49. Berry MN, Phillips JW, Grivell AR. Interactions between mitochondria and cytoplasm in isolated hepatocytes. Curr Top Cell Regul 1992;33:309-328.

50. Colowick SP. Separation of proteins by use of adsorbents. Methods Enzymol 1955; 1:91-98.

51. Bergmeyer HU, editor. Enzyme assays. Vol. 2. 3rd ed. New York: John Wiley \& Sons Inc.; 1986.

52. Schuck P. Sedimentation analysis of noninteracting and selfassociating solutes using numerical solutions to the Lamm equation. Biophys J 1998;75:1503-1512.

53. Honig B, Nicholls A. Classical electrostatics in biology and chemisty. Science 1995;268:1144-1149.

54. Beeckmans S, Kanarek L. Demonstration of physical interactions between consecutive enzymes of the citric acid cycle and of the aspartate-malate shuttle. A study involving fumarase, malate dehydrogenase, citrate synthase and aspartate aminotransferase. Eur J Biochem 1981:117:527-535.

55. Beeckmans S, Van Driessche E, Kanarek L. The visualization by affinity electrophoresis of a specific association between the consecutive citric acid cycle enzymes fumarase and malate dehydrogenase. Eur J Biochem 1989;183:449-454.

56. Cann JR. Theory and practice of gel electrophoresis of interacting macromolecules. Anal Biochem 1996;237:1-16.
57. Miekka SI, Ingham KC. Influence of hetero-association on the precipitation of proteins by poly(ethylene glycol). Arch Biochem Biophys 1980;203:630-641.

58. Ingham KC. Protein precipitation with polyethylene glycol. Methods Enzymol 1984;104:351-356.

59. Philo J. Meassuring sedimentation, diffusion, and molecular weights of small molecules by direct fitting of sedimentation velocity concentration profiles. In: Schuster T, Laue T, editors. Modern analytical ultracentrifugation. Boston: Basel; Berlin: Birkhauser; 1994. p 350.

60. Hoskins AA, Anand R, Ealick SE, Stubbe J. The formylglycinamide ribonucleotide amidotransferase complex from Bacillus subtilis: metabolite-mediated complex formation. Biochemistry 2004;43:10314-10327.

61. Scheek RM, Slater EC. Glyceraldehyde-3-phosphate dehydrogenase from rabbit muscle. Methods Enzymol 1982;89(Pt D):305309.

62. Holbrook JJ, Liljas S, Steindel SJ, Rossman MG, editors. Lactate dehydrogenase. 3rd ed. Vol. XI. New York: Academic Press; 1975.

63. Harris JI, Waters M, editors. Glyceraldehyde-3-phosphate dehydrogenase. 3rd ed. Vol. XIII. New York: Academic Press; 1976.

64. Velot C, Mixon MB, Teige M, Srere PA. Model of a quinary structure between Krebs TCA cycle enzymes: a model for the metabolon. Biochemistry 1997;36:14271-14276.

65. Cowan-Jacob SW, Kaufmann M, Anselmo AN, Stark W, Grutter MG. Structure of rabbit-muscle glyceraldehyde-3-phosphate dehydrogenase. Acta Crystallogr D Biol Crystallogr 2003;59:22182227.

66. Grau UM, Trommer WE, Rossmann MG. Structure of the active ternary complex of pig heart lactate dehydrogenase with S-lacNAD at 2.7 A resolution. J Mol Biol 1981;151:289-307.

67. Read JA, Winter VJ, Eszes CM, Sessions RB, Brady RL. Structural basis for altered activity of M- and H-isozyme forms of human lactate dehydrogenase. Proteins 2001;43:175-185.

68. Newsholme EA, Leech AR. Biochemistry for medical students. New York: Wiley; 1985.

69. Newsholme EA, Board M. Application of metabolic-control logic to fuel utilization and its significance in tumor cells. Adv Enzyme Regul 1991;31:225-246.

70. Pearson WR, Wood T, Zhang Z, Miller W. Comparison of DNA sequences with protein sequences. Genomics 1997;46:24-36.

71. Rossman MG, Liljas A, Branden C-I, Banaszak LJ. Evolutionary and structural relationships among dehydrogenase. In: Boyer PD, editor. The enzymes. 3rd ed. Vol. XI. New York: Academic Press, 1975. p 61-102.

72. Lehoux EA, Baker SM, Kovina MV, Hays FA, Spivey HO. Absence of evidence for metabolite-modulated association between alphaglycerol-3-phosphate dehydrogenase and L-lactate dehydrogenase. Biochemistry 2003;42:6259-6263.

73. Dunn CR, Wilks HM, Halsall DJ, Atkinson T, Clarke AR, Muirhead H, Holbrook JJ.. Design and synthesis of new enzymes based on the lactate dehydrogenase framework. Philos Trans R Soc Lond B Biol Sci 1991;332:177-184.

74. Mercer WD, Winn SI, Watson HC. Twinning in crystals of human skeletal muscle D-glyceraldehyde-3- phosphate dehydrogenase. J Mol Biol 1976;104:277-283. 